\title{
Factors That Affect The Performance Of Logistics Employees At Pharmaceutical Wholesalers X In Banjarmasin
}

\author{
Tuti Alawiyah ${ }^{1^{*}}$ \\ ${ }^{1}$ Management Master Of Economics Banjarmasin Indonesia, \\ Tuticiput88@gmail.com
}

Yanuar Backhtia ${ }^{1}$,

${ }^{1}$ Management Master Of Economics Banjarmasin Indonesia,

*Yanuar@gmail.com

Ibrahim Daud ${ }^{1}$

${ }^{1}$ Management Master Of Economics Banjarmasin Indonesia, ibrahim_daud@gmail.com

\begin{abstract}
Objective: To analyze Factor of leadership style, motivation and training in partially influencing logistics employee performance at pharmaceutical wholesalers X in Banjarmasin

Method: The research was conducted in the form of analytical research with the object of pharmaceutical wholesalers in Banjarmasin, the population in this study was 47 employees of logistics employees at a pharmaceutical wholesaler in Banjarmasin. The sampling technique of this research was saturated sample technique

Result: the result of calculation by computer showed that: leadership style partially significant effect on logistics employee performance at pharmaceutical wholesaler by significant value 0,02 , motivation partially significant effect on logistic employees performance at pharmaceutical wholesaler by significant value 0,019 , training partially significant effect to logistic employees performance pharmaceutical wholesaler by significant value 0,027

Conclusion: the result of all variables can be seen that leadership style, motivation and training partially influence to logistics performance Logistics employees performance at Pharmaceutical Wholesalers in Banjarmasin
\end{abstract}

Keywords: Leadership style, Motivation, Pharmaceutical Wholesalers, Training.

\section{INTRODUCTION}

The drug is one of the pharmaceutical preparations and is an irreplaceable basic human need in the health service, so the drug should not be treated as a mere economic commodity [1]. To ensure the quality, efficacy, safety and validity of the drug to the consumer, including the distribution network of drugs A drug distribution network (pharmaceutical industry, pharmaceutical wholesalers, pharmacies and drug retailers) should establish a quality assurance system so that distributed drugs are assured of quality, efficacy, safety, and legitimacy to the consumer [2]. This system is conducted in line with Quality Assurance System that has been done by Pharmaceutical Industry in carrying out its activities. The drug distribution network should ensure that the drugs distributed have circulation permits, with appropriate storage conditions maintained and monitored. In conjunction with this, the Indonesian Food and Drug Supervisory Agency has drafted the Guidelines on How to Distribute Good 
Drugs referring to Good Distribution Practices (GDP) for Pharmaceutical Products, WHO, 2006, and Good Manufacturing Practice Guidelines [3].

The Principles of Good Drug Distribution are applicable to aspects of procurement, storage, distribution including the return of drugs and/or medicinal materials in the distribution chain. All parties involved in the distribution process must apply prudential principles in compliance with the principles of Good Drug Distribution, for example in procedures related to search engagement and risk identification. The process of distribution or distribution of pharmaceutical preparations is a means used to distribute or distribute pharmaceutical preparations, ie pharmaceutical wholesalers, and pharmaceutical preparations. Pharmaceutical wholesalers are companies in the form of legal entities that have licenses for the procurement, storage, distribution of drugs and/or medicines in large quantities in accordance with the provisions of legislation [4].

In the implementation, it is necessary to develop a distributor of Pharmaceutical Wholesalers on How to Distribute Good Drugs As well as the examination conducted by the Food and Drug Supervisory Agency in Banjarmasin 2014 there are 41 Pharmaceutical Wholesalers of South Kalimantan related to the fulfillment of Good Medicine Distribution criteria and do not meet the criteria are as follows : there are $53 \%$ who meet the criteria and $47 \%$ do not meet the criteria, and in 2015 (January -
August period) the result of examination data in 41 Pharmaceutical wholesalers are $55 \%$ who meet the criteria and $45 \%$ do not meet the criteria [5]. One of the most successful aspects of the successful method of Good Drug Distribution is the aspect of quality management in the distribution of drugs, namely the procurement process, storage, distribution including the return of drugs. is and all critical stages of the distribution process and meaningful change must be validated and documented. The quality system should include quality risk management principles. Achieving quality objectives is the responsibility of the person in charge of the distribution facility, requires leadership and active participation and must be supported by top management commitment.

Principles Quality management on the distribution that meets the criteria of a determination by the drug and food supervisory bodies cannot be separated from the performance of logistics employees in the fulfillment of the quality assurance of a drug. Employee performance is the result of a person as a whole during a certain period in carrying out the task (6), such as the standard of work in the criteria of drug distribution assurance to ensure the quality is guaranteed in accordance with the provisions have been set by the drug regulatory agency and eat in the distribution chain process Many factors affect employee performance, including job satisfaction factors, discipline factors, leadership factors, motivation factors, and training factors, but according to observations made by 
researchers to various big traders of pharmaceutical matters the problem of Good Drug Distribution in quality assurance is the lack of training of logistics employees against the things that exist in the aspect of How to Distribute Good Drugs in Pharmaceutical Wholesalers, the employees are poorly trained in the guarantee of warehouse quality in the Pharmaceutical Wholesaler, another thing observation during observation is the lack of motivation of logistics employees in running and maintaining quality management. as well as influential leadership styles in employee performance logistics, This research will further look at the factors that affect the employee's logical performance on pharmaceutical wholesalers $X$ in Banjarmasin.

\section{METHODS}

This study uses a quantitative approach that is digging based on statistical calculations using a descriptive method that is after dig and calculated with the numbers then elaborated with words or explanations of the questionnaires that have been disseminated to the respondents. Variable in this research consist of independent variable or independent variable that is: Leadership style, Motivation, training and dependent variable or dependent variable that is: Employee Performance on pharmaceutical wholesalers X Banjarmasin.

The population in this study were all employees of logistics in pharmaceutical wholesalers $\mathrm{X}$ amounted to 47 people to examine the performance of logistics employees in pharmaceutical wholesalers, with sampling technique saturated or census which amounted to 47 people.

The location of this research is in pharmaceutical wholesalers $\mathrm{X}$ located in eastern Banjar region with 3 months research period (January - March 2017). Data collection with questionnaires made using Likert Scale five-level Likert Scale is the interval data, therefore Parametric Parametric Parameter Testing tools can be used. Interviews/interviews are question and answer done to logistics employees in pharmaceutical wholesalers to ask for explanations related to the intent of the questionnaire and to enrich the observation analysis by doing a direct observation of the variables of leadership style, motivation, and training.

Data collection in this research is obtained from Primary Data is original data collected by the researcher himself to answer the problem of research especially. Primary data in this research is obtained through a questionnaire. Secondary data is the power that has been collected by others, not by the researcher himself. The secondary data in this study comes from corporate documents

The analysis used in this study is statistical analysis of regression, which is used to answer the research hypothesis The style of leadership, motivation and training partially and simultaneously affect the performance of logistics employees in pharmaceutical wholesalers $\mathrm{X}$ in Banjarmasin in addition to answering the purpose of research that is Analyzing 
Influence Leadership style, Motivation and training on employees performance logistics at pharmacy wholesalers in Banjarmasin.

The data used in this research is primary and secondary data, by method

a. Classic assumption test is done by regression test process. Multiple linear regression models can be termed as good models if they satisfy classical statistical assumptions that include heteroscedasticity, linearity and normality test

b. Multiple linear analysis is used to measure the influence between more than one predictive variable (independent variable) to the dependent variable. This analysis is to know the direction of the relationship between the independent variable is positive or negative and to predict the value of the dependent variable if the value of the independent variable increases or decreases. Criteria of the conclusion of the test results is that if the value of $p$ value (significant value) is smaller than the value of e 0.05 (a predetermined significance level) then it means there is a linear influence between independent variables X1 leadership style, X2 Motivation and X3 training with variable $\mathrm{Y}$ performance of logistics employees of pharmaceutical wholesalers

\section{RESULTS}

Table 1 Characteristics of respondents

\begin{tabular}{|c|c|c|}
\hline characteristics & Frequency & $\begin{array}{c}\text { Percentage } \\
(\%)\end{array}$ \\
\hline \multicolumn{3}{|l|}{ age } \\
\hline $20-29$ & 25 & 53,20 \\
\hline $30-39$ & 16 & 34,04 \\
\hline$>40$ & 6 & 12,76 \\
\hline \multicolumn{3}{|l|}{ Gender } \\
\hline Male & 38 & 80,85 \\
\hline Female & 9 & 19,15 \\
\hline \multicolumn{3}{|l|}{ education } \\
\hline Senior high school & 15 & 71,43 \\
\hline Diploma & 6 & 28,57 \\
\hline Bachelor & 13 & 27,66 \\
\hline
\end{tabular}

a.1 Heteroscedasticity Test; from the analysis results show the graph there is no clear pattern, but the points spread out above and below the number 0 on the $y$-axis, then there is no heteroscedasticity.

\section{a.2 linearity test}

Table 2 Linearity of variable relationship with employee performance

\begin{tabular}{llll}
\hline & $\begin{array}{l}\text { Leadership } \\
\text { style }\end{array}$ & $\begin{array}{l}\text { Motivati } \\
\text { on }\end{array}$ & Training \\
\hline $\mathrm{N}$ & 47 & 47 & 47 \\
\hline $\begin{array}{l}\text { (Deviation } \\
\text { from } \\
\text { Linierity) }\end{array}$ & 0,636 & 0,903 & 0,393 \\
\hline
\end{tabular}

a.3 Normality test

normality test results there are data spread around the diagonal line and follow diagonal army direction, then the regression model meets the assumption of normality worthy of use to predict the performance according to the input of all independent variables

\section{b. T-test result}

Table 3 of regression coefficients between leadership style variables, motivation, training with employee performance logistics

\begin{tabular}{llll}
\hline & $\begin{array}{l}\text { Leadership } \\
\text { style }\end{array}$ & $\begin{array}{l}\text { Motivati } \\
\text { on }\end{array}$ & Training \\
\hline $\mathrm{N}$ & 47 & 47 & 47 \\
\hline $\mathrm{t}$ & 0,019 & 0,027 \\
$\begin{array}{l}\text { koefisi } \\
\text { en }\end{array}$ & 0,02 & & \\
\hline
\end{tabular}




\section{DISCUSSION}

The result of research proved that the factor of leadership style has a significant influence on the performance of logistic employees in pharmaceutical wholesalers.The $t$ value of statistical leadership style (X1) variables partially significant effect on the performance of logistics employees in pharmaceutical wholesalers.

Based on the result of the recapitulation of the average percentage of questionnaire style compliance this leadership style is supported by the results of research conducted by (7) which proves that leadership style positively affects employee performance. The style of leadership affects the performance of logistics employees, interpreted if the style of leadership is indicated by the authority lead in the eyes of employees, defined when the style of leadership is shown with the authority of leaders in the eyes of employees, and leaders can be subordinate role model, then the employee performance will increase. This condition occurs because the role of leader as a top manager, which functions in moving and empowering employees (8). Good leadership will make employees feel calm in the work, so it can improve employee performance. A leadership style that suits the employees of logistics is a democratic leadership style, Democratic leadership style is the style of leader who gives widespread authority to subordinates. Every problem always involves subordinates as a whole team. In a democratic leadership style, the leader provides much information about the duties and responsibilities of his subordinates. Subordinates must participate in providing suggestions, ideas, and considerations in the decision-making process. Decisions are still done by taking the leadership suggestions and ideas given subordinates. Broadly outlined by (9) a leader, in general, must have the following characteristics:

a. A leader is able to analyze and draw the right conclusions.

b. A leader has the ability to organize an organization, can select and place the people who become subordinates to occupy positions in organisms concerned.

c. A leader also has the ability to create in such a way that the organization runs smoothly to achieve goals, ideals and decisions from higher levels to employees so that objectives and decisions that can be received well by employees.

Work motivation significantly influences the performance of logistics employee pharmaceutical wholesalers with value $t$ statistic variable of work motivation (X2) this result is smaller than value 0,05 which means motivation variable partially influence to performance of logistic merchant of pharmacy trader. Research Results (10) support a statement of significant value on motivation to employee performance. To encourage a person to do activities, motivation to give positive value and lead to perceived value, motivation can improve the standard of living for someone to be better. For some employees, the hope of earning money is the only reason to work, but others argue that money is just one of 
many needs fulfilled through work (11). A person who works will feel more appreciated by the people around him, than those who do not work. They will feel more appreciated again when receiving various facilities and other status symbols from companies where they work. From the above description can be said, that the willingness of employees to devote their skills, knowledge, skills, manpower, and time, actually expect a reward from the company that can satisfy their needs. For that motivation is needed to improve the performance of the employees, so that the quality assurance of drug distribution and profit the company can continue to grow. determine what factors influence motivation in the organization. There is a difference between the factors that cause dissatisfaction and job satisfaction so that satisfaction is the opposite of dissatisfaction. The opposite of job satisfaction is no satisfaction, and the opposite of dissatisfaction is no discontent. Two tools of activity that satisfy human needs are:

a. a. Needs related to job satisfaction or also called motivation. These needs include achievement, reward, responsibility, progress or promotion, the job itself, and the potential for personal growth. When these factors are absent in the workplace, employees will lack motivation, but by no means are not satisfied with their work.

b. Needs related to job dissatisfaction or also called hygiene. These needs include salary, supervision, security, working conditions, administration, organizational policy, and interpersonal relationships with the environment or work context. When these factors are positively responded, employees do not experience satisfaction or appear to be motivated, but if they do not exist, employees will feel dissatisfied.

Training affects the performance of logistics employee big pharmaceutical employee with significant value $\mathrm{t}$ Training variable (X3) result is smaller than the value of 0.05 which means the partial training variables affect the performance of logistics pharmaceutical wholesale merchants. It can be concluded that training has a significant contribution in improving employee performance. The results of this study are in line with the research conducted by (12) which revealed a significant contribution between training and employee performance logistics with a positive direction, meaning that if training gets better, then employee performance will increase. The training given periodically and the results of research obtained directly applied in the field. To be able to achieve good performance, the skills and skills possessed by logistics employees should be good, and this will happen if there is a training intended for employees as expected. The training program aims to have human resources that have optimum performance. With the existence of training activities, employees have the opportunity to absorb knowledge and skills, so as to improve the profession in carrying out the tasks assigned to him. Other research results by (13) The results showed that the training has a positive effect on the performance of the store prime employee. This is evidenced by the result of t-test for motivation variable 
obtained significant level 0,003 , because at alpha 5\% significant level less than 0,005 (sig <0,5), and regression coefficient have a positive value. Training is one way that affects individuals to achieve specific things according to individual goals. that training programs Training programs or with the term "Training" is one of the company's strategic programs in order to maintain and provide motivation to employees. [14] Employees usually have the necessary skills and basic skills. It is not uncommon for employees who are accepted to have no ability to fully perform their job duties. Even experienced employees need to learn to adjust to organizations, policies and company procedures [15].This training is intended for new employees and long-time employees of the organization. So that will be obtained the quality of employees who have the skills evenly, which will ultimately be very supportive in the process of achieving organizational goals.

\section{CONCLUSION}

Based on the results of research that has been done, obtained some conclusions as follows: Leadership style has a significant effect on the performance of employees of logistics Wholesalers of Pharmaceuticals, with a significant value of 0.02 , the motivation significantly influence the performance of logistics employees Wholesalers of Pharmaceuticals with a significant value 0.019 , on the performance of logistics employees of Wholesalers of Pharmaceuticals with a significant value of 0.027 .

\section{REFERENCES}

[1] Departemen Kesehatan RI, Pokok Program dan Program Perencanaan Pembangunan Kesehatan Мепијu Indonesia Sehat 2010

[2] Departemen Kesehatan RI, Peraturan Menteri Kesehatan RI No. 1191, Perubahan atas Peraturan Menteri Kesehatan, 2002

[3] Badan Pengawas Obat dan Makanan, Pedoman Cara Distribusi Obat yang Baik,Jakarta, 2007

[4] Departemen Kesehatan RI, Peraturan Menteri Kesehatan RI No. 1148 pedangang besar Farmasi, 2011

[5] Badan Pengawas Obat dan Makanan, Daftar Periksa (Checklist) Pemetaan PBF PBBBF, Banjarmasin, 2016

[6] Iqbal, aliya, farah Latif “ Factors effecting the employee's performance",2015 European jur vol IV (08) p 309-318

[7] Ganda, Wijaya Pengaruh Gaya kepemimpinan, Motivasi, dan disiplin kerja terhadap kinerja karyawan PT. Surya Makmur agung Lestari dinamika manajemen 2013, vol 2 145160

[8] Becker, T.E \& Kernan, M.C. 2003. matching commitment to supervisors and organizations to in-role and extrarole performance. Human Performance, 16(4), 327-348.

[9] Andiana Pengaruh Motivasi dan Kemampuan Terhadap Kinerja Karyawan CV. Mulia Jaya Abadi 2012, Tesis Fakultas Ekonom dan Bisnis Universitas Islam Negeri Syarif Hidayatullah 2012

[10] Andrew, D., \& Kent, R. (2007). The Impact of Perceived Leadership Behaviors on Satisfaction, Commitment, and Motivation: An Expansion of the multidimensional model of Leadership. International Journal of Coaching Science, 1(1), 3556 
[11] Arep, Ishak dan Hendri Tanjung. Manajemen Sumber Daya Manusia. Jakarta: Universitas Trisakti.2003

[12] Ariyani ida, Siti Haerani, The Influence of Organizational Culture, Work Motivation and Working Climate on the Performance of Nurses through Job Satisfaction, Organizational Commitment and Organizational Citizenship Behavior in the Private Hospitals in Jakarta, Indonesia Scientific Research Journal, 2012 ; IV (7) :p $15-28$

[13] Kraak, A. 2005. Human Resources Development and the Skills Crisis in South Africa: the Need for Multipronged Strategy. Journal of Education and Work 18,1,57-83.
[14] Becker, T.E \& Kernan, M.C. 2003. matching commitment to supervisors and organizations to in-role and extrarole performance. Human Performance, 16(4), 327-348.

[15] Swart, J., Mann, C., Brown, S. \& Price, A. 2005. Human Resource Development: Strategy and Tactics. Oxford. Elsevier ButterworthHeinemann Publications. 